From Accelerated Accumulation to Socialist Market Economy in China 


\title{
China Studies
}

PUBLISHED FOR THE INSTITUTE FOR CHINESE STUDIES, UNIVERSITY OF OXFORD

\author{
Edited by
}

Micah Muscolino (University of Oxford)

VOLUME 38

The titles published in this series are listed at brill.com/chs 


\title{
From Accelerated Accumulation to Socialist Market Economy in China
}

\author{
Economic Discourse and Development from \\ 1953 to the Present
}

By

Kjeld Erik Brødsgaard and Koen Rutten

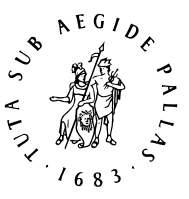

B R I L L 


\section{B R I L L \\ OPE N}

This is an open access title distributed under the terms of the CC-BY-NC License, which permits any non-commercial use, distribution, and reproduction in any medium, provided the original author(s) and source are credited.

HII

An electronic version of this book is freely available, thanks to the support of libraries working with Knowledge Unlatched. More information about the initiative can be found at www.knowledgeunlatched.org.

Library of Congress Control Number: 2017931917

Typeface for the Latin, Greek, and Cyrillic scripts: “Brill”. See and download: brill.com/brill-typeface.

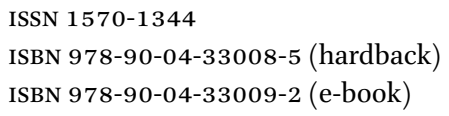

Copyright 2017 by Kjeld Erik Brødsgaard and Koen Rutten.

This work is published by Koninklijke Brill NV. Koninklijke Brill NV incorporates the imprints Brill, Brill Hes \& De Graaf, Brill Nijhoff, Brill Rodopi and Hotei Publishing.

Koninklijke Brill NV reserves the right to protect the publication against unauthorized use and to authorize dissemination by means of offprints, legitimate photocopies, microform editions, reprints, translations, and secondary information sources, such as abstracting and indexing services including databases. Requests for commercial re-use, use of parts of the publication, and/or translations must be addressed to Koninklijke Brill NV.

This book is printed on acid-free paper and produced in a sustainable manner. 


\section{Contents}

Preface IX

List of Figures $\mathrm{X}$

List of Tables XI

1 Introduction 1

Changes and Continuities in Chinese Development (1953-Present) 3 Explanations of Change within Chinese Economic Governance 6

Discourse, Economic Paradigms and Governance 12

A Discursive Explanation of Change and Continuity in China's Mode of Governance 13

2 Primitive Socialist Accumulation, Readjustment and Reform

(1953-1978) 17

Introduction 17

Theoretical Foundations and Issues of Communist Development $\quad 18$

The Law of Value and the Law of Planned Proportionate

Development 18

Accelerated Accumulation and Balanced Growth $\quad 22$

Fel'dman's Theory of Accumulation 22

Preobrazhensky and Primitive Socialist Accumulation 23

Bukharin and the Limits to Socialist Primitive Accumulation 24

The Productive Forces and the Relations of Production 25

Economic Discourse and Policy in the Maoist Era (1953-1977) 27

The First Five Year Plan (1953-1957) 27

The Great Leap Forward (1958-1959) 33

Readjustment and Consolidation (1960-1965) 36

Readjustment, Consolidation, Filling Out and Raising

Standards 38

The Roles of Price and Profit Reevaluated 42

The Cultural Revolution 44

Economic Development under the Maoist Economic Paradigm 46

Conclusion $5^{0}$

3 Market Allocation and Enterprise Reform in the Primary Stage of

Capitalism (1978-1992) 53

Introduction 53

The Pragmatist Turn and the Liberalization of Economic

Discourse 55 
Early Reforms and Readjustment (1978-1986) 57

Chen Yun's Reforms Vindicated 57

Opening Up: China's Special Economic Zones 59

Readjustment 64

Reform and Recentralization, Balanced and Accelerated

Growth 67

The Sixth Five Year Plan (1981-1985): From Plan Economy to

Macro-control 70

Price and Ownership Reform, Inflation and the Origins of the

Tiananmen Incident $\quad 78$

Tiananmen and the Reemergence of Conservatism 84

Economic Developments in the First Phase of Reform 86

Conclusion 91

4 The Emergence and Development of the Socialist Market Economy (1992-2003) 94

Introduction 94

The Second Liberation of Thought and the Marginalization of

Socialist Diagnostics 95

Ownership, Interest and Property Rights 98

The Formulation of a Socialist Market Economy 101

Fiscal and Monetary Reform and the Reinvigoration of the Central

State 106

The Retrenchment of Public Industry and the Debate on

Ownership 110

A Turning Point in the Development of the Socialist Market Economy: From the Modern Enterprise System to Grasping the Large and Releasing the Small 113

Stabilization, the Advance of the Non-State Economy and the

Stagnation of Reform 118

Economic Developments within the Socialist Market Economy

(1992-2003) 122

Conclusion 125

5 Scientific Development and Domestic Demand (2003-2011) 128

Introduction 128

Distributive Concerns and the Dynamics of Growth 129

Readjustment Revisited: Western Development, Urbanization and

the Revitalization of Agriculture 130

From Extensive to Intensive Development: Nurturing the

Indigenous Capacity for Innovation 135 
The Scientific Development Concept 138

Developing Domestic Demand, Constructing a New Countryside and the Advantage of Large Nations: Theory and Policy under Jiang and $\mathrm{Hu} \quad 140$

Scientific Development and the Keynesian Guise of the Chinese State 142

Economic Development under the 11th Five Year Plan (2006-2010) $\quad 146$

Conclusion 150

6 The Era of Xi Jinping (2012-2016) 154

Massive Overcapacity 158

Zombie Enterprises 160

13th Five Year Plan and New Normal $\quad 162$

Conclusion 164

7 Discourse and Development: Insights and issues 165

Introduction 165

Readjustment and Reform: From Plan to Socialist Market

Economy $\quad 166$

Discourse and Politics 170

Merits and Limitations of Discursive Analysis 171

Dynamics of Discourse: Insights from the Chinese Case 173

Conclusion $\quad 176$

References 179

Index 209 
Kjeld Erik Brødsgaard and Koen Rutten - 9789004330092 Downloaded from Brill.comఠ4/26/2023 03:32: 02PM via free access 


\section{Preface}

The purpose of this project is to provide new insight into the ongoing structural transformation of the Chinese economic system and concomitant economic developments by examining the role of economic ideas and discourse. The origins of this project date back to the early 1980s. In 1983, Kjeld Erik Brødsgaard, then a doctoral student at the University of Copenhagen, published a two-part article in the journal of Modern China, which comprehensively described the joint development of Chinese economic discourse and the economic system from the implementation of the First Five Year Plan in 1953 until the early years of reform in 1981. In his Ph.D. dissertation from 1989 entitled "Readjustment and Reform in the Chinese Economy 1953-1986" he took the analysis to the year 1986. Pervasive interest in the drivers of China's remarkable economic transformation, and growing attention to the role of discourse in shaping the development of economic systems, made this an opportune time to reinitiate the project that Professor Brødsgaard commenced some 30 years ago. This book builds on his initial findings and extends them to present times. The analysis first presented in Modern China provides the basis for the first chapter and most of the second chapter, and informs the general approach taken within this study. In collaboration with Professor Brødsgaard, Dr. Koen Rutten has sought to supplement the analysis by introducing concepts from recent institutional theory and examining the joint development of economy and discourse in the last two decades. Kjeld Erik Brødsgaard has added a chapter on $\mathrm{Xi}$ Jinping, thereby bringing the analysis up to the present time. We hope the result will inspire new appreciation of the role of economic discourse in the ongoing project of Chinese economic development that started some seven decades ago.

The authors gratefully acknowledge the financial support provided by the EAC Foundation, without which this project would have been impossible. We also wish to express our gratitude to the Department of Economics and Management at Copenhagen Business School for hosting the project and to the Universities Service Centre, Hong Kong, for providing access to the center's unique collection of material on China's economic development. We also duly recognize the efforts of Xinru Zhang who assisted in preparing the manuscript for publication. Additionally, we would like to thank Nis Grunberg, Mart Platje and especially Robert F. Ash for insightful and encouraging comments on early drafts. Finally, Koen Rutten would like to express his gratitude to his wife Lin Lei, whose unconditional support has been significant for the completion of this project. 


\section{List of Figures}

1 Growth rate of GDP (\%), household consumption expenditure (HCE) and gross fixed capital formation (GFCF), 1953-2011 5

2 GFCF and HCE as proportion of total GDP (\%), 1952-2012 5

3 GFCF as ratio of GDP and percentage growth (\%), 1952-1978 46

4 Growth indices of output of primary and secondary industry, 1952-1978 47

5 Sectoral composition of GDP, 1978-1992 88

6 GDP growth and inflation, 1978-1992 (percentage change over previous year) 89

7 Industrial output, employment and investment in fixed assets of TVEs as ratio of SOEs, 1980-1992 90

8 Revenues and expenditure of local government, 1992-1997 112

9 Share of gross value of industrial value by ownership, 1998-2003 119

10 GDP and component growth, 1992-2003 (percentage growth) 124

11 Urban investment in fixed assets as share of total, 1998-2010 144

12 Year-on-year percentage growth of household consumption and incomes under three diverging fiscal policies, 1998-2011 147

13 Utilization rates for six industries (\%) $\quad 159$ 


\section{List of Tables}

1 Sectoral composition of GDP, 1953-2012 (\%) 6

2 Total and per capita output of selected products in China and the Soviet Union at the outset of their First Five Year Plans 29

3 Planning the Great Leap Forward: Production quota for grain and steel output for the year $1962 \quad 35$

4 Capital construction and GFCF as a percentage of GDP, 1978-1985 66

5 Average annual growth rates of agriculture, 1952-1984 87

6 Fiscal revenues, 1990-1995 108

7 Indicators of fiscal and monetary policy and inflation, 1991-1996 (\%) 109

8 Indicators of SOE 121

9 Indicators of concentration within SOE, 1998-2003 123

10 Share of industrial investment in fixed assets by sector, 2003-2010 (\%) 146

11 Economic growth rates in China, 2002-2015 (\%) 148

12 Chinese capital formation 2000-2015 (share of GDP (\%)) 149 